\title{
COVID-19 and periodontitis: reflecting on a possible association
}

\author{
Giuseppina Campisi ${ }^{1 \dagger}$, Maria Eleonora Bizzoca ${ }^{2+}$ and Lorenzo Lo Muzio $2,3^{* \dagger}$
}

\begin{abstract}
Recent studies have demonstrated a relationship between the severe clinical course of COVID-19 and other chronic diseases such as: cardiovascular disease, hypertension, diabetes mellitus, obesity and chronic renal disease. It may be possible to extend this association to a common and chronic oral disease in adults: periodontitis. Alternatively, the latter could be simply related to the systemic chronic diseases cited above, as already observed in the nonCOVID-19 literature. In order to provide an overview and their opinion, the authors in this perspective article will report and discuss the most recent references of interest relating to COVID-19 and periodontitis pathophysiology. Within such a narrative review, the authors will hypothesize that the association between chronic periodontitis and COVID-19 could exist via two pathways: a direct link, through the ACEII and CD147 receptors used by the virus to infect the cells, which would occur in greater numbers in cases of periodontitis (thereby favoring a SARS-CoV-2 infection); and/or an indirect pathway involving the overexpression of inflammatory molecules, especially IL-6 and IL-17. An expression of the latter has been found to play a role in periodontitis, in addition to severe cases of COVID-19, although it is still unclear if it plays a direct role in the worsening of the clinical course.
\end{abstract}

Keywords: Periodontitis, COVID-19, Coronavirus, SARS-CoV-2, IL-6, IL-17

\section{Introduction}

Coronavirus disease 2019 (COVID-19), due to SARS-CoV2 , is the most pressing and emergent health problem worldwide. While most cases result in mild symptoms (including hyposalivation and an alteration in taste [1]), some cases progress to severe pneumonia and multi-organ failure with the death of the patient, according to the age and the presence of comorbidities [2]. Recent relevant studies have demonstrated the bidirectional association between the severe clinical course of COVID-19 and chronic diseases such as: cardiovascular disease, hypertension, diabetes mellitus, obesity and chronic renal disease [1, 3-5]. In

\footnotetext{
* Correspondence: Iorenzo.lomuzio@unifg.it

${ }^{\dagger}$ Campisi Giuseppina, Bizzoca Maria Eleonora and Lo Muzio Lorenzo contributed equally to this work.

${ }^{2}$ Department of Clinical and Experimental Medicine, University of Foggia, Via Rovelli, 50, 71122 Foggia, Italy

${ }^{3}$ C.I.N.B.O. (Consorzio Interuniversitario Nazionale per la Bio-Oncologia), Chieti, Italy

Full list of author information is available at the end of the article
}

seeking a link between COVID-19 and these chronic diseases, they are garnering worldwide interest in the field of research. This interest may also be extended to include more common, chronic oral diseases in adults, such as periodontitis [6], with already demonstrated correlations and associations with other chronic diseases, as mentioned above [7]. The authors in this perspective article will report the most recent references of interest regarding COVID-19 and periodontal physiopathology in order to improve our understanding of associated or randomly associated factors.

Data from the literature [8-12] has confirmed that the majority of COVID-19 positive patients are male. And male sex was observed to be an independent risk factor, which was associated with refractory disease and death ( $2.8 \%$ death rate for men vs. $1.7 \%$ for female) $[11,13]$. With reference to the hypothesis in this article concerning the association between periodontal pathophysiology and COVID-19, let us begin with the argumentation of the studies showing that SARS-CoV-2 also enters the

(c) The Author(s). 2021 Open Access This article is licensed under a Creative Commons Attribution 4.0 International License, which permits use, sharing, adaptation, distribution and reproduction in any medium or format, as long as you give appropriate credit to the original author(s) and the source, provide a link to the Creative Commons licence, and indicate if changes were made. The images or other third party material in this article are included in the article's Creative Commons licence, unless indicated otherwise in a credit line to the material. If material is not included in the article's Creative Commons licence and your intended use is not permitted by statutory regulation or exceeds the permitted use, you will need to obtain permission directly from the copyright holder. To view a copy of this licence, visit http://creativecommons.org/licenses/by/4.0/. The Creative Commons Public Domain Dedication waiver (http://creativecommons.org/publicdomain/zero/1.0/) applies to the data made available in this article, unless otherwise stated in a credit line to the data. 
human body via the oral mucosa $[1,14]$ through the Angiotensin Converting Enzyme II (ACE2) receptor [15-17], which is highly expressed in the oral mucosa (mostly in the epithelial cells of the tongue) $[16,18]$ and in the salivary glands [5].

A study by Pascolo et al. has demonstrated the necessary co-expression of ACE2 and trans-membrane serine protease (TMPRSS2), to enable the entry of SARS-CoV2 into host cells [19]. Indeed, the TMPRSS and furin serve to cleave the virus $\mathrm{S}$ protein and thereafter spread the infection [20]. Recently, preliminary data has speculated a new infection route for SARS-CoV-2, in which this virus could use its spike protein to bind to CD147 in order to infect human cells [21]. In support of the hypothesis outlined in this article, this would, therefore, result in a high expression of CD147 in the epithelial cells, particularly those of the oral mucosa [22, 23]. Additional data lending credence to the speculation in this article is that SARS-CoV-2 resides in saliva and nasopharynx in such quantities so as to render swabs with these samples useful for COVID-19 diagnostic tests [24-26]. Furthermore, a recent study by Gupta et al. has demonstrated the presence of SARS-CoV-2 in gingival crevicular fluid (GCF), with a sensitivity of the diagnostic swab of $63.64 \%$ (a salivary swab has a sensitivity of approximately 64\%) [24]. Hence, the fact that SARS-CoV-2 stagnates in the GCF may lead us to conclude that poor oral hygiene may increase the viral load in the oral cavity.

Two possible mechanisms which could explain the association between periodontitis and the COVID-19 disease are: (1) the direct contact of virus with the periodontal tissues, also due to the high expression of ACEII and CD147, as mentioned above; and/or (2) the similar overexpression of several cytokines, a COVID-19 'cytokine storm', with elevated serum levels of IL-1 beta, IL-6, IL-7, IL-10, IL-17, IL-2, IL-8, IL-9, GM-CSF, GCSF, IFN-gamma, TNF alpha, MIP1A, MIP1B, MCP1 and IP10 [27, 28].

In this regard, the authors of this article have analysed the literature data concerning IL- 6 and IL-17, which is also overexpressed in periodontitis [29]. Several studies have suggested the role of IL- 6 in the pathogenetic mechanisms of COVID-19 [30-35]: when SARS-CoV-2 infects the respiratory tract, it induces a release of proinflammatory cytokines, including interleukin (IL)-1beta and IL-6 [31]. One of the mechanisms making the coronavirus lethal could be the induction of interstitial pneumonia, which is in turn linked to an overproduction of IL-6 $[34,36]$. Similarly, IL-17 has high levels in the serum of COVID-19 patients [27]. In a recent study, an increase in IL-17, and 14 other cytokines, levels were positively correlated with a higher Murray score for lung injuries [28]. Notwithstanding this, some authors have hypothesized that the role of IL-6 merely serves as a reliable biomarker for the early detection and progression of COVID-19 [37]. Periodontal disease has also been recognized as a cytokine storm-generating disease, especially in the presence of other chronic dysmetabolic diseases, such as diabetes [12, 38-40]. Indeed, diabetes can cause a chronic activation of the immune system with increased levels of circulating leukocytes and pro-inflammatory markers [41]; these include serum levels of inflammation-related biomarkers such as IL-6, C-reactive protein, serum ferritin and the D-dimer coagulation index [42].

\section{Focus on periodontitis}

Periodontitis (i.e. plaque-related periodontal disease) is defined as "a chronic, multifactorial inflammatory disease, associated with dysbiotic plaque biofilms and characterized by the progressive destruction of the tooth-supporting apparatus" [43, 44], and classified by staging and grading systems [45]. The disease of periodontitis is globally widespread: in China it has been estimated that the prevalence of the severe variant is $1.9 \%$, and that those with diabetes are 2.4 times more likely to possess this variant [46]. In recent years there has been particular interest in probable associations between periodontal infection and systemic diseases [38]. Indeed, periodontal pathogens and their products (including inflammatory mediators such as IL-6) could enter the bloodstream, thereby causing several systemic diseases. Chronic periodontitis has been shown to be a risk factor for: cardiovascular disease, diabetes mellitus, respiratory disease, rheumatoid arthritis and other conditions [38]. Indeed, periodontopathic bacteria were found in the bronchoalveolar lavage fluid of patients suffering from pneumonia [47]. In turn, diabetes could increase the risk of developing pneumonia [42, 48, 49] and, thus, the association of periodontitis and diabetes could multiply the risk of pneumonia even in the absence of the SARS-CoV-2 infection $[1,50]$.

It is of note that periodontitis has a documented, higher prevalence in men $(\sim 57 \%)$ as compared to women $(\sim 39 \%)$, thereby signifying a possible sex involvement in disease pathogenesis [51]. Furthermore, there are several microbial exchanges (primarily $\mathrm{S}$. mutans, P. intermedia, F. nucleatum and P. gingivalis) between the oral cavity and the lungs [52, 53], and tooth decay and periodontitis are the oral diseases which are predominantly involved in oral bacterial disequilibrium [54]. In order to explain these exchanges (and, therefore, respiratory infections), two hypotheses have been proposed; (1) cytokines and enzymes produced during a periodontal disease may alter the respiratory epithelium and oral mucosa, thereby favoring infection; and (2) the aspiration of oral pathogens into the lungs [55]. Thus, 
poor oral hygiene can increase the risk of such mouthlung exchanges and, therefore, respiratory infections, especially in patients over the age of $70[56,57]$.

A previous study has shown that there was an increase in IL-17-producing cells in the gingival tissue of patients suffering from gingivitis and periodontitis, as compared to healthy controls [58]. The same authors reported have elevated levels of IL-17 in the serum of patients with periodontal disease [58]. The systemic inflammatory burden of periodontitis is also well-documented by virtue of the presence of the marked sensitivity of the $\mathrm{C}$ reactive protein (hsCRP), a component of positive Acute Phase Proteins (APPs), which increase during a phlogistic process [58-60]. Indeed, there is evidence regarding increased levels of chemokine- and cytokine-producing cells in the epithelium of periodontopathic patients, and increased levels of these inflammatory markers in the serum of the same patients $[61,62]$. Another positive APP is Galectin-3 (Gal-3), a pro-inflammatory protein which is involved in several mechanisms such as: inflammation, angiogenesis, cell growth, host defence and others [63]. Moreover, elevated levels of Gal-3 are related to severe periodontitis [62]. Finally, a correlation between Gal-3 and SARS-CoV-2 was observed in a recent study in which the morphology of Gal-3 was observed to be similar to the SARS-CoV-2 spike protein [64-67].

\section{Perspective hypothesis: is there any association between COVID-19 and periodontitis?}

Basing our hypotheses on the most recent literature and, therefore, on that which has been definitively demonstrated for periodontitis, several events would seem to correlate with the clinical behavior of COVID-19 with a patient's periodontal status. By causing ulceration of the gingival epithelium, periodontitis could reduce the protective function of the oral epithelial cells, thereby exposing the patients to an elevated risk of invasion by SARS-CoV-2 [1]. Concurrently, ACE2, TMPRSS2 and furin, which are expressed in the aforementioned oral epithelial cells and the proteases produced by periodontopathic bacteria, could cleave the protein $\mathrm{S}$ of the virus, thereby favoring infection. It, therefore, follows that the presence of periodontopathic bacteria could increase the risk of SARS-CoV-2 infection [68].

Various studies have shown that the oral, subgingivalcomponent epithelial cells of periodontal pockets express high levels of CD147 [22, 23] and thus, periodontitis could facilitate SARS-CoV-2 infection through the CD147 route.

Takahashi $Y$ et al., have argued (with their unpublished data) that, when periodontopathic bacteria are aspirated into the lungs, the expression of ACE2 increases in the bronchus and the lungs (also in the oral cavity) due to bacterial and pathogenic factors, such as endotoxins, and that this overexpression could increase the risk of a SARS-CoV-2 infection [68].

In a recent study by Takahashi $\mathrm{Y}$ et al., the culture supernatant of the periodontopathic bacterium Fusobacterium nucleatum (CSF) has been shown to upregulate the angiotensin converting enzyme 2 of the SARS-CoV2 receptor in alveolar epithelial cells [69]. Furthermore, CSF induced the production of interleukin (IL) -6 and IL-8 by alveolar epithelial cells; CSF also strongly induced the expression of IL- 6 and IL- 8 by bronchial epithelial cells of pharyngeal epithelial cells. These findings suggest that when patients with mild COVID-19 frequently aspirate periodontopathic bacteria, SARS-CoV-2 infection is promoted, and lower respiratory tract inflammation can become severe in the presence of viral pneumonia [69].

Moreover, Marouf $\mathrm{N}$ et al., in a case-control study, demonstrated that periodontitis was associated with higher risk of intensive care unit admission, need for assisted ventilation and death of COVID-19 patients, and with increased blood levels of biomarkers linked to worse disease outcomes [70].

Other researchers have hypothesized that, in a given patient with periodontal disease the periodontal situation during a SARS-CoV-2 infection could be aggravated due to the downregulation of ACE2 and an increase in ACE and Ang II, thereby resulting in the involvement of several pro-inflammatory factors $[71,72]$. It is also noteworthy that periodontopathic bacteria have been found in the metagenome of severe COVID-19 patients [73]; indeed, it is commonplace to find bacterial superinfections in patients with severe cases of COVID-19 [74].

It is clear that respiratory viral infections could predispose patients to bacterial superinfections, resulting in increased disease severity and mortality [75]. Indeed, strains of the coronavirus have been shown to improve the adhesion of streptococcus to epithelial cells of the respiratory tract, causing complications such as pneumonia and inflammatory damage in the lungs and consequent inhibition of the clearance of bacteria [75]. Finally, a recent study has demonstrated that intensive periodontal treatment reduced the risk of pneumonia in COVID-19 patients [48].

Albeit indirect, another possible mechanism, which could explain the association between periodontal disease and a severe COVID-19 course, could be the overproduction of phlogistic molecules, such as IL-6 and IL-17, in healthy patients and patients with chronic diseases such as diabetes. It should be considered that periodontitis, independently of any other pathology, raises IL-6. Therefore and irrespective of the concept that IL-6 is the cause of severe cases of COVID-19 or a reliable biomarker for COVID-19 [37], periodontitis could modify the level of IL-6 in COVID-19 patients. It can also be hypothesized that in those COVID-19 patients, 
also suffering from diabetes and periodontitis, levels of IL-6 in circulation deriving from all three pathologies could be envisaged.

Considering the aforementioned research, it is the considered opinion of the authors of this perspective article that it merits further discussion in encouraging reflection and/or experimental studies in the following fields: an analysis of the association and/or risk of periodontitis in COVID-19/diabetic patients, who are at greater risk of and developing both diseases; and to ascertain whether the use of molecules against the Sprotein (and, therefore, against Gal-3, or vice versa) could be useful in disrupting the attachment of the virus to the host cells and indecreasing the production of IL-1 and IL-6.

\section{Acknowledgements}

The authors wish to thank J. O Davies for the positive contribution to language editing.

\section{Authors' contributions}

The authors of this perspective article have contributed in equal measure to the conceptualization, methodology, validation, investigation, writing of the original draft and preparation, writing of the review and editing, and supervision of this research; all authors have approved the submitted version (and any substantially modified version that involves the author's contribution to the study); all authors have agreed both to be personally accountable for the author's own contributions and to ensure that questions related to the accuracy or integrity of any part of the work, even ones in which the author was not personally involved, are appropriately investigated, resolved, and the resolution documented in the literature.

\section{Funding}

Not applicable.

\section{Availability of data and materials}

Data sharing is not applicable to this article as no datasets were generated or analysed during the current study.

\section{Declarations}

Ethics approval and consent to participate

Not applicable.

\section{Consent for publication}

Not applicable.

\section{Competing interests}

The authors declare that they have no competing interests.

\section{Author details}

${ }^{1}$ Department of Surgical, Oncological and Oral Sciences, University of Palermo, Palermo, Italy. ${ }^{2}$ Department of Clinical and Experimental Medicine, University of Foggia, Via Rovelli, 50, 71122 Foggia, Italy. ${ }^{3}$ C.I.N.B.O. (Consorzio Interuniversitario Nazionale per la Bio-Oncologia), Chieti, Italy.

Received: 28 December 2020 Accepted: 4 May 2021

Published online: 11 May 2021

\section{References}

1. Pfützner A, Lazzara M, Jantz J. Why Do People With Diabetes Have a High Risk for Severe COVID-19 Disease?-A Dental Hypothesis and Possible Prevention Strategy. J Diabetes Sci Technol. 2020;14(4):769-71. https://doi. org/10.1177/1932296820930287.

2. Hui DS, Madani EIA, Ntoumi TA, Kock F, Dar R. O, et al. The continuing 2019-nCoV epidemic threat of novel coronaviruses to global health -
The latest 2019 novel coronavirus outbreak in Wuhan, China. Int J Infect Dis. 2020;91:264-6.

3. Rathi M, Jeloka T, Prasad N, Bansal S, Agarwal SK, Bhalla AK, et al. Chronic kidney disease and hypertension with reference to COVID-19. Indian J Nephrol. 2020;30(3):155-7.

4. Rapp JL, Lieberman-Cribbin W, Tuminello S, Taioli E. Male Sex, Severe Obesity, Older Age, and Chronic Kidney Disease Are Associated With COVID-19 Severity and Mortality in New York City. Chest. 2021;159(1):112-15. https://doi.org/10.1016/j.chest.2020.08.2065.

5. Pedrosa MDS, Neves Nogueira F. COVID-19 and Diabetes: What Should We Expect? J Diabetes Sci Technol. 2020;14(6):1133-4. https://doi.org/10.1177/1 932296820948041.

6. Sahni V, Gupta S. COVID-19 \& Periodontitis: the cytokine connection. Med Hypotheses. 2020;144:109908.

7. Sukumar K, Tadepalli A. Nexus between COVID-19 and periodontal disease. J Int Med Res. 2021;49(3):3000605211002695.

8. Lipsky MS, Hung M. Men and COVID-19: a pathophysiologic review. Am J Mens Health. 2020;14(5):1557988320954021.

9. Walter LA, McGregor AJ. Sex- and Gender-specific Observations and Implications for COVID-19. West J Emerg Med. 2020;21(3):507-9. https://doi. org/10.5811/westjem.2020.4.47536

10. Onder G, Rezza G, Brusaferro S. Case-fatality rate and characteristics of patients dying in relation to COVID-19 in Italy. JAMA. 2020;323(18):1775-6.

11. Chen N, Zhou M, Dong X, Qu J, Gong F, Han Y, et al. Epidemiological and clinical characteristics of 99 cases of 2019 novel coronavirus pneumonia in Wuhan, China: a descriptive study. Lancet. 2020;395(10223):507-13.

12. Bischof E, Wolfe J, Klein SL. Clinical trials for COVID-19 should include sex as a variable. J Clin Invest. 2020;130(7):3350-2.

13. Mo $P$, Xing $Y$, Xiao $Y$, Deng $L$, Zhao $Q$, Wang $H$, Xiong $Y$, Cheng $Z$, Gao $S$, Liang K, Luo M, Chen T, Song S, Ma Z, Chen X, Zheng R, Cao Q, Wang F, Zhang Y. Clinical characteristics of refractory COVID-19 pneumonia in Wuhan, China. Clin Infect Dis. 2020;ciaa270. https://doi.org/10.1093/cid/ciaa2 70 .

14. Madapusi Balaji T, Varadarajan S, Rao USV, Raj AT, Patil S, Arakeri G, et al. Oral cancer and periodontal disease increase the risk of COVID 19? A mechanism mediated through furin and cathepsin overexpression. Med Hypotheses. 2020;144:109936.

15. Zhou P, Yang XL, Wang XG, Hu B, Zhang L, Zhang W, et al. A pneumonia outbreak associated with a new coronavirus of probable bat origin. Nature. 2020;579(7798):270-3.

16. Xu H, Zhong L, Deng J, Peng J, Dan H, Zeng X, et al. High expression of ACE2 receptor of 2019-nCoV on the epithelial cells of oral mucosa. Int J Oral Sci. 2020;12(1):8

17. Badran Z, Gaudin A, Struillou X, Amador G, Soueidan A. Periodontal pockets: A potential reservoir for SARS-CoV-2? Med Hypotheses. 2020;143:109907.

18. Descamps G, Verset L, Trelcat A, et al. ACE2 Protein Landscape in the Head and Neck Region: The Conundrum of SARS-CoV-2 Infection. Biology (Basel). 2020;9(8):235. https://doi.org/10.3390/biology9080235.

19. Pascolo L, Zupin L, Melato M, Tricarico PM, Crovella S. TMPRSS2 and ACE2 coexpression in SARS-CoV-2 salivary glands infection. J Dent Res. 2020; 99(10):1120-1.

20. Hoffmann M, Kleine-Weber H, Schroeder S, Kruger N, Herrler T, Erichsen S, et al. SARS-CoV-2 cell entry depends on ACE2 and TMPRSS2 and is blocked by a clinically proven protease inhibitor. Cell. 2020;181(2):271-80. e8.

21. Wang $K$, Chen W, Zhou Y-S, Lian J-Q, Zhang Z, Du P. SARS-CoV-2 invades host cells via a novel route: CD147-spike protein. BioRxiv. 2020:2020.03. 14988345.

22. Feldman M, La VD, Lombardo Bedran TB, Palomari Spolidorio DM, Grenier D. Porphyromonas gingivalis-mediated shedding of extracellular matrix metalloproteinase inducer (EMMPRIN) by oral epithelial cells: a potential role in inflammatory periodontal disease. Microbes Infect. 2011;13(14-15):1261-9.

23. Wang J, Yang D, Li C, Shang S, Xiang J. Expression of extracellular matrix metalloproteinase inducer glycosylation and caveolin-1 in healthy and inflamed human gingiva. J Periodontal Res. 2014;49(2):197-204.

24. Gupta S, Mohindra R, Chauhan PK, Singla V, Goyal K, Sahni V, Gaur R, Verma DK, Ghosh A, Soni RK, Suri V, Bhalla A, Singh MP. SARS-CoV-2 Detection in Gingival Crevicular Fluid. J Dent Res. 2021;100(2):187-93. https://doi.org/1 $0.1177 / 0022034520970536$

25. Fernandes Matuck B, Dolhnikoff M, Maia GVA, Isaac Sendyk D, Zarpellon A, Costa Gomes S, et al. Periodontal tissues are targets for Sars-Cov-2: a postmortem study. J Oral Microbiol. 2020;13(1):1848135. 
26. Elisetti N. Periodontal pocket and COVID-19: Could there be a possible link? Med Hypotheses. 2021;146:110355.

27. Wu D, Yang XO. TH17 responses in cytokine storm of COVID-19: An emerging target of JAK2 inhibitor Fedratinib. J Microbiol Immunol Infect. 2020;53(3):368-70.

28. Pacha O, Sallman MA, Evans SE. COVID-19: a case for inhibiting IL-17? Nat Rev Immunol. 2020;20(6):345-6.

29. Raisanen IT, Umeizudike KA, Parnanen P, Heikkila P, Tervahartiala T, Nwhator SO, et al. Periodontal disease and targeted prevention using aMMP-8 pointof-care oral fluid analytics in the COVID-19 era. Med Hypotheses. 2020;144: 110276.

30. Ascierto PA, Fox BA, Urba WJ, Anderson AC, Atkins MB, Borden EC, Brahmer JR, Butterfield LH, Cesano A, Chen DC, de Gruijl TD, Dillman RO, Drake CG, Emens LA, Gajewski TF, Gulley JL, Stephen Hodi FJ, Hwu P, Kaufman D, Kaufman HL, Lotze MT, McNeel DG, Margolin KM, Marincola FM, Mastrangelo MJ, Maus MV, Parkinson DR, Romero PJ, Sondel PM, Spranger S, Sznol M, Weiner GJ, Wigginton JM, Weber JS. Insights from immunooncology: the Society for Immunotherapy of Cancer Statement on access to IL-6-targeting therapies for COVID-19. J Immunother Cancer. 2020;8(1): e000878. https://doi.org/10.1136/jitc-2020-000878.

31. Conti P, Ronconi G, Caraffa A, Gallenga CE, Ross R, Frydas I, Kritas SK. Induction of pro-inflammatory cytokines (IL-1 and IL-6) and lung inflammation by Coronavirus-19 (COVI-19 or SARS-CoV-2): anti-inflammatory strategies. J Biol Regul Homeost Agents. 2020;34(2):327-31. https://doi.org/1 0.23812/CONTI-E.

32. Lagunas-Rangel FA, Chávez-Valencia V. High IL-6/IFN- $\gamma$ ratio could be associated with severe disease in COVID-19 patients. J Med Virol. 2020 92(10):1789-90. https://doi.org/10.1002/jmv.25900.

33. Liu B, Li M, Zhou Z, Guan X, Xiang Y. Can we use interleukin-6 (IL-6) blockade for coronavirus disease 2019 (COVID-19)-induced cytokine release syndrome (CRS)? J Autoimmun. 2020;111:102452. https://doi.org/10.1016/j.ja ut.2020.102452.

34. Zhang C, Wu Z, Li JW, Zhao H, Wang GQ. Cytokine release syndrome in severe COVID-19: interleukin-6 receptor antagonist tocilizumab may be the key to reduce mortality. Int J Antimicrob Agents. 2020;55(5):105954. https:// doi.org/10.1016/j.jiantimicag.2020.105954.

35. Zhao M. Cytokine storm and immunomodulatory therapy in COVID-19: Role of chloroquine and anti-IL-6 monoclonal antibodies. Int J Antimicrob Agents. 2020;55(6):105982. https://doi.org/10.1016/j.ijantimicag.2020.105982.

36. Chen X, Zhao B, Qu Y, Chen Y, Xiong J, Feng Y, Men D, Huang Q, Liu Y, Yang B, Ding J, Li F. Detectable Serum Severe Acute Respiratory Syndrome Coronavirus 2 Viral Load (RNAemia) Is Closely Correlated With Drastically Elevated Interleukin 6 Level in Critically III Patients With Coronavirus Disease 2019. Clin Infect Dis. 2020;71(8):1937-42. https://doi.org/10.1093/cid/ciaa449.

37. Wang C, Fei D, Li X, Zhao M, Yu K. IL-6 may be a good biomarker for earlier detection of COVID-19 progression. Intensive Care Med. 2020;46(7):1475-6.

38. Pizzo G, Guiglia R, Lo Russo L, Campisi G. Dentistry and internal medicine: from the focal infection theory to the periodontal medicine concept. Eur J Intern Med. 2010;21(6):496-502

39. Pitones-Rubio V, Chavez-Cortez EG, Hurtado-Camarena A, Gonzalez-Rascon A, Serafin-Higuera N. Is periodontal disease a risk factor for severe COVID-19 illness? Med Hypotheses. 2020;144:109969.

40. Aquino-Martinez R, Hernández-Viqueras S. Severe COVID-19 Lung Infection in Older People and Periodontitis. J Clin Med. 2021;10(2):279. https://doi. org/10.3390/jcm10020279.

41. Corbella S, Francetti L, Taschieri S, De Siena F, Fabbro MD. Effect of periodontal treatment on glycemic control of patients with diabetes: a systematic review and meta-analysis. J Diabetes Investig. 2013;4(5):502-9.

42. Guo W, Li M, Dong Y, Zhou H, Zhang Z, Tian C, Qin R, Wang H, Shen Y, Du $K$, Zhao L, Fan H, Luo S, Hu D. Diabetes is a risk factor for the progression and prognosis of COVID-19. Diabetes Metab Res Rev. 2020;e3319. https:// doi.org/10.1002/dmrr.3319.

43. Papapanou PN, Sanz M, Buduneli N, Dietrich T, Feres M, Fine DH, et al. Periodontitis: consensus report of workgroup 2 of the 2017 World Workshop on the Classification of Periodontal and Peri-Implant Diseases and Conditions. J Clin Periodontol. 2018:45(Suppl 20):162-S70.

44. Butera A, Maiorani C, Natoli V, Bruni A, Coscione C, Magliano G, Giacobbo G, Morelli A, Moressa S, Scribante A. Bio-Inspired Systems in Nonsurgical Periodontal Therapy to Reduce Contaminated Aerosol during COVID-19: A Comprehensive and Bibliometric Review. J Clin Med. 2020;9(12):3914. https://doi.org/10.3390/jcm9123914.
45. Tonetti MS, Greenwell H, Kornman KS. Staging and grading of periodontitis: Framework and proposal of a new classification and case definition. J Periodontol. 2018;89(Suppl 1):159-S72.

46. Zhang Q, Li Z, Wang C, Shen T, Yang Y, Chotivichien S, et al. Prevalence and predictors for periodontitis among adults in China, 2010. Glob Health Action. 2014;7:24503

47. Yamasaki K, Kawanami T, Yatera K, Fukuda K, Noguchi S, Nagata S, et al. Significance of anaerobes and oral bacteria in community-acquired pneumonia. PLoS One. 2013;8(5):e63103.

48. Yang LC, Suen YJ, Wang YH, Lin TC, Yu HC, Chang YC. The Association of Periodontal Treatment and Decreased Pneumonia: A Nationwide Population-Based Cohort Study. Int J Environ Res Public Health. 2020;17(1): 356. https://doi.org/10.3390/ijerph17010356.

49. Botros $N$, lyer $P$, Ojcius DM. Is there an association between oral health and severity of COVID-19 complications? Biomed J. 2020;43(4):325-7. https://doi. org/10.1016/j.bj.2020.05.016.

50. Giuseppina Campisi, Maria Eleonora Bizzoca, Lorenzo Lo Muzio. A new exciting hypothesis: direct correlation between periodontitis and clinical evolution of COVID-19 patients. Qeios. 2020. https://doi.org/10.32388/ WK61AM.3.

51. Ioannidou E. The Sex and Gender Intersection in Chronic Periodontitis. Front Public Health. 2017:5:189.

52. Mathieu E, Escribano-Vazquez U, Descamps D, Cherbuy C, Langella P, Riffault $\mathrm{S}$, et al. Paradigms of lung microbiota functions in health and disease, particularly, in asthma. Front Physiol. 2018:9:1168.

53. Scannapieco FA, Genco RJ. Association of periodontal infections with atherosclerotic and pulmonary diseases. J Periodontal Res. 1999;34(7):340-5.

54. Sampson V, Kamona N, Sampson A. Could there be a link between oral hygiene and the severity of SARS-CoV-2 infections? Br Dent J. 2020;228(12):971-5.

55. Hayata M, Watanabe N, Tamura M, Kamio N, Tanaka H, Nodomi K, et al. The periodontopathic bacterium fusobacterium nucleatum induced proinflammatory cytokine production by human respiratory epithelial cell lines and in the lower respiratory organs in mice. Cell Physiol Biochem. 2019;53(1):49-61.

56. Sjogren $P$, Nilsson E, Forsell $M$, Johansson $O$, Hoogstraate J. A systematic review of the preventive effect of oral hygiene on pneumonia and respiratory tract infection in elderly people in hospitals and nursing homes: effect estimates and methodological quality of randomized controlled trials. J Am Geriatr Soc. 2008;56(11):2124-30.

57. Coke CJ, Davison B, Fields N, Fletcher J, Rollings J, Roberson L, Challagundla KB, Sampath C, Cade J, Farmer-Dixon C, Gangula PR. SARS-CoV-2 Infection and Oral Health: Therapeutic Opportunities and Challenges. J Clin Med. 2021;10(1):156. https://doi.org/10.3390/jcm10010156.

58. Graves D. Cytokines that promote periodontal tissue destruction. J Periodontol. 2008;79(8 Suppl):1585-91.

59. Amabile N, Susini G, Pettenati-Soubayroux I, Bonello L, Gil JM, Arques S, et al. Severity of periodontal disease correlates to inflammatory systemic status and independently predicts the presence and angiographic extent of stable coronary artery disease. J Intern Med. 2008;263(6):644-52.

60. Artese HP, Foz AM, Rabelo Mde S, Gomes GH, Orlandi M, Suvan J, et al. Periodontal therapy and systemic inflammation in type 2 diabetes mellitus: a meta-analysis. PLoS One. 2015;10(5):e0128344.

61. Liccardo D, Cannavo A, Spagnuolo G, Ferrara N, Cittadini A, Rengo C, Rengo G. Periodontal Disease: A Risk Factor for Diabetes and Cardiovascular Disease. Int J Mol Sci. 2019;20(6):1414. https://doi.org/10.3390/ijms20061414.

62. Kara C, Çelen K, Dede FÖ, Gökmenoğlu C, Kara NB. Is periodontal disease a risk factor for developing severe Covid-19 infection? The potential role of Galectin-3. Exp Biol Med (Maywood). 2020;245(16):1425-7. https://doi.org/1 $0.1177 / 1535370220953771$.

63. Liu FT. Galectins: a new family of regulators of inflammation. Clin Immunol. 2000;97(2):79-88.

64. Caniglia JL, Guda MR, Asuthkar S, Tsung AJ, Velpula KK. A potential role for Galectin-3 inhibitors in the treatment of COVID-19. PeerJ. 2020;8:e9392.

65. Moore JB, June $\mathrm{CH}$. Cytokine release syndrome in severe COVID-19. Science. 2020;368(6490):473-4

66. Li W, Hulswit RJG, Widjaja I, Raj VS, McBride R, Peng W, et al. Identification of sialic acid-binding function for the Middle East respiratory syndrome coronavirus spike glycoprotein. Proc Natl Acad Sci U S A. 2017;114(40):E8508-E17.

67. Li F, Structure. Function, and Evolution of Coronavirus Spike Proteins. Annu Rev Virol. 2016;3(1):237-61.

68. Takahashi Y, Watanabe N, Kamio N, Kobayashi R, linuma T, Imai K. Aspiration of periodontopathic bacteria due to poor oral hygiene potentially 
contributes to the aggravation of COVID-19. J Oral Sci. 2020;63(1):1-3. https://doi.org/10.2334/josnusd.20-0388.

69. Takahashi Y, Watanabe N, Kamio N, Yokoe S, Suzuki R, Sato S, linuma T, Imai K. Expression of the SARS-CoV-2 Receptor ACE2 and Proinflammatory Cytokines Induced by the Periodontopathic Bacterium Fusobacterium nucleatum in Human Respiratory Epithelial Cells. Int J Mol Sci. 2021;22(3): 1352. https://doi.org/10.3390/ijms22031352.

70. Marouf N, Cai W, Said KN, Daas H, Diab H, Chinta VR, Hssain AA, Nicolau B, Sanz M, Tamimi F. Association between periodontitis and severity of COVID19 infection: A case-control study. J Clin Periodontol. 2021;48(4):483-91. https://doi.org/10.1111/jcpe.13435.

71. Mancini L, Quinzi V, Mummolo S, Marzo G, Marchetti E. Angiotensinconverting enzyme 2 as a possible correlation between COVID-19 and periodontal disease. Appl Sci. 2020;10:6224.

72. Silhol F, Sarlon G, Deharo JC, Vaisse B. Downregulation of ACE2 induces overstimulation of the renin-angiotensin system in COVID-19: should we block the renin-angiotensin system? Hypertens Res. 2020;43(8):854-6.

73. Chakraborty SS. Metagenome of SARS-CoV2 patients in Shenzhen with travel to Wuhan shows a wide range of species - Lautropia, Cutibacterium, Haemophilus being most abundant - and Campylobacter explaining diarrehoea. 2020. Available online at https://osfio/jegwq (Accessed June 2020).

74. Cox MJ, Loman N, Bogaert D, O'Grady J. Co-infections: potentially lethal and unexplored in COVID-19. Lancet Microbe. 2020;1 (1):e11. https://doi.org/10.1 016/S2666-5247(20)30009-4.

75. Sampson V, Kamona N, Sampson A. Could there be a link between oral hygiene and the severity of SARS-CoV-2 infections? Br Dent J. 2020;228(12): 971-5. https://doi.org/10.1038/s41415-020-1747-8.

\section{Publisher's Note}

Springer Nature remains neutral with regard to jurisdictional claims in published maps and institutional affiliations.

Ready to submit your research? Choose BMC and benefit from:

- fast, convenient online submission

- thorough peer review by experienced researchers in your field

- rapid publication on acceptance

- support for research data, including large and complex data types

- gold Open Access which fosters wider collaboration and increased citations

- maximum visibility for your research: over $100 \mathrm{M}$ website views per year

At $\mathrm{BMC}$, research is always in progress.

Learn more biomedcentral.com/submissions 